\title{
'Gumdrop', a New Early Harvest Pistachio Cultivar
}

Craig E. Kallsen

University of California Cooperative Extension, 1031 South Mount Vernon Avenue, Bakersfield, CA 93307

\section{Dan E. Parfitt ${ }^{1}$}

Department of Plant Science, University of California, One Shields Avenue, Davis CA 95616

\section{Additional index words. Pistacia vera, nut breeding}

Abstract. 'Gumdrop' is a new female pistachio (Pistacia vera $\mathbf{L}$.) cultivar for California. It matures earlier than all commercial cultivars with equivalent yield and nut quality to 'Kerman'. 'Gumdrop' can be harvested about 10-12 days before 'Golden Hills' pistachio (Parfitt et al., 2007) and 24 days before 'Kerman', the standard pistachio cultivar grown in California (Parfitt et al., 2012). 'Gumdrop' has very good yield, nut quality, and processed nut appearance similar to 'Golden Hills' and 'Kerman'. 'Gumdrop' blooms about 5 days before 'Golden Hills' and 10-11 days before 'Kerman'. 'Gumdrop', 'Golden Hills', and 'Kerman' comprise a harvest series, maturing over a 24-30 day period. The early nut maturity of 'Gumdrop' will permit pistachio growers to extend their harvest period. The earlier maturing date of 'Gumdrop' also makes it less susceptible to insect damage from navel orangeworm, a major pest of pistachio implicated in the occurrence of aflatoxin contamination. An application for a U.S. Plant Patent was submitted on 4 Apr. 2016.
'Gumdrop' is an open-pollinated offspring of female seedling 'B15-69', located in a selection plot near Famoso, CA, with 1410 seedlings, described in Chao et al. (1998). 'B15-69' was developed as part of the Parfitt, Kallsen, and Maranto breeding project in the 1990s (Kallsen et al., 2009), from a cross of female 2-35, originally selected by Dr. J. Crane in the 1970 s, and ES2, an early flowering male of unknown parentage. 'Gumdrop' was selected as seedling S-43 (one of 35 seedlings from 'B15-69' seed) for precocity, early season nut maturity, and nut size in 2006 from a breeding selection plot, established near Bakersfield California in 2001. 'Gumdrop', 'Kerman', and 'Golden Hills' were grafted onto UCB1 rootstock and tested in a randomized block trial (three blocks, four to six trees per cultivar/block) established near Buttonwillow CA in 2007. This trial is located near the center of the major U.S. pistachio-growing region.

\section{Description}

Tree. 'Gumdrop' is a large, vigorous tree on UCB1 rootstock. The crown is somewhat irregular in shape, more so than for 'Golden Hills' or 'Kerman' (Fig. 1). Tree structure is similar to 'Kerman' with scaffold branch angles $80^{\circ}$ to $90^{\circ}$. It forms fewer scaffolds than 'Golden Hills'. Primary and secondary branches are stiff, which facilitates shaking to remove the nuts for harvest. Bark color is gray, similar to 'Kerman' and

Received for publication 21 Sept. 2016. Accepted for publication 1 Dec. 2016.

${ }^{1}$ Corresponding author. E-mail: deparfitt@ucdavis. edu.
'Golden Hills' (202C to 202D). Color evaluations are from the Royal Horticultural Society Color Chart (R.H.S. color chart v. 3 QC495 R8 V.1-4).

Leaves. Leaves are deciduous simple compound imparipinnate with one or two pairs of oppositely arranged lateral leaflets. Leaflet margins are entire to slightly crenate. Leaflets are oval to ovate and 5-8 cm long. Leaflets vary considerably in shape, in general being ovate with cuspidate to rounded tips and rounded base. Leaflets are somewhat larger than for 'Kerman' and 'Golden Hills'. Margins of leaf blades are entire. Leaf surfaces are glabrous, smooth, and waxy. Leaves range from light green at first emergence to

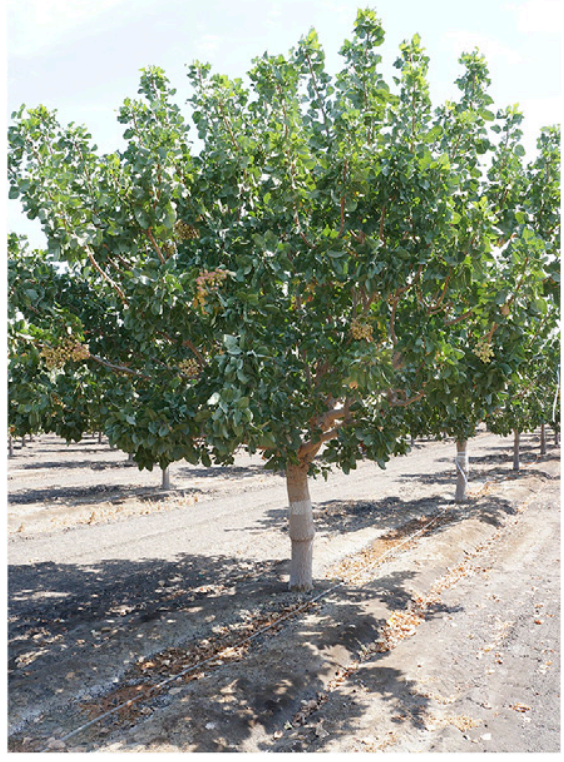

Fig. 1. 'Gumdrop' in replicated trial on the west side of the San Joaquin valley, showing tree size and large nut clusters.

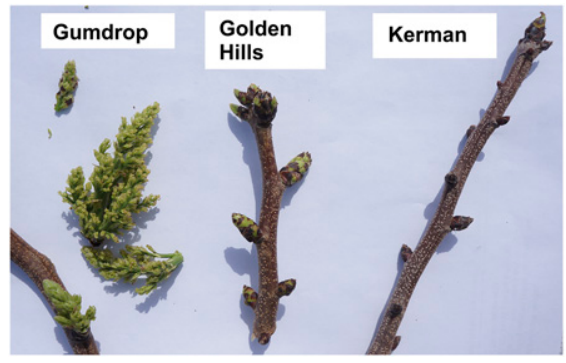

Fig. 2. Inflorescences of 'Gumdrop', 'Golden Hills', and 'Kerman' pistachio on 20 Mar. 2014, showing differences in development. All shoots were collected on the same date (20 Mar. 2014).
Table 1. Bloom ratings over four years for 'Gumdrop', 'Golden Hills', and 'Kerman'.

\begin{tabular}{lccccc}
\hline Cultivar & \multicolumn{5}{c}{ Bloom rating on each date } \\
\cline { 1 - 6 } \cline { 3 - 6 } 2012 & 20 Mar. 2012 & 27 Mar. 2012 & 5 Apr. 2012 & 12 Apr. 2012 & 17 Apr. 2012 \\
\hline Gumdrop & 0.5 & 2.3 & 3.3 & 5.0 & 6.0 \\
Golden Hills & 0.2 & 0.5 & 2.1 & 3.5 & 4.7 \\
Kerman & 0.0 & 0.2 & 0.2 & 2.5 & 3.4
\end{tabular}

2014 6 Mar. 2014 14 Mar. 2014 20 Mar. 2014 26 Mar. $2014 \quad 4$ Apr. 2014 11 Apr. 2014

\begin{tabular}{lllllll}
\hline Gumdrop & 0.2 & 1.0 & 2.9 & 6.0 & 6.0 & 6.0 \\
Golden Hills & 0.0 & 0.0 & 1.2 & 2.5 & 4.3 & 6.0 \\
Kerman & 0.0 & 0.0 & 0.2 & 2.1 & 3.0 & 5.0
\end{tabular}

\begin{tabular}{|c|c|c|c|c|c|c|}
\hline 2015 & 10 Mar. 2015 & 18 Mar. 2015 & 23 Mar. 2015 & 20 Mar. 2015 & 2 Apr. 2015 & 9 Apr. 2015 \\
\hline Gumdrop & 0.0 & 2.3 & 4.5 & 5.0 & 6.0 & 6.0 \\
\hline Golden Hills & 0.0 & 0.0 & 1.0 & 1.3 & 3.5 & 4.5 \\
\hline Kerman & 0.0 & 0.0 & 0.0 & 0.5 & 3.5 & 4.0 \\
\hline
\end{tabular}

\begin{tabular}{|c|c|c|c|c|c|c|}
\hline 2016 & 4 Mar. 2016 & 16 Mar. 2016 & 18 Mar. 2016 & 23 Mar. 2016 & 28 Mar. 2016 & 1 Apr. 2016 \\
\hline Gumdrop & 0.4 & 1.8 & 3.0 & 5.0 & 6.0 & 6.0 \\
\hline Golden Hills & 0.0 & 0.4 & 0.9 & 3.5 & 5.0 & 6.0 \\
\hline Kerman & 0.0 & 0.1 & 0.2 & 1.0 & 3.0 & 4.5 \\
\hline
\end{tabular}

${ }^{\mathrm{z}}$ Bloom ratings 0 to 6 .

$0=$ dormant buds, $1=$ green tip on flower bud, $2=>5$ open buds on tree, $3=$ mid bloom, $4=$ full bloom, $5=$ late bloom, $6=$ bloom finished. 
dark green at maturity with no difference between upper and lower leaf surfaces. Color ratings from three or more mature leaves were 139B for the upper and lower surfaces and for new leaves $138 \mathrm{~B}$ to $139 \mathrm{C}$ and $139 \mathrm{C}$ for the lower surface. Leaf midrib color was $143 \mathrm{C}$.

Flowers. Female inflorescences are born laterally on 1-year-old wood. One hundred to more than 200 female flowers are present on panicle inflorescences with $8-15$ branches/

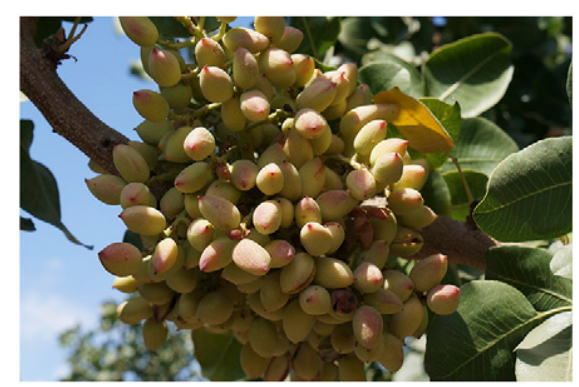

Fig. 3. 'Gumdrop' pistachio nut cluster at maturity, showing the general size and shape of the cluster, number of nuts, and distribution of nuts in the cluster.

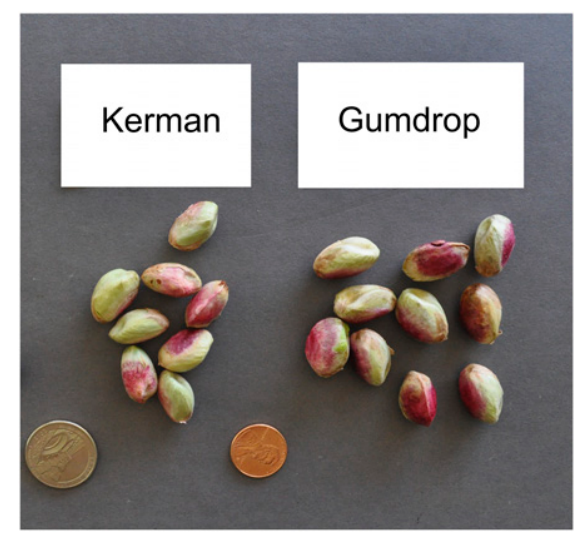

Fig. 4. Kernels of 'Kerman' and 'Gumdrop' pistachios. inflorescence (Fig. 2). Flower numbers per influence are highly variable among inflorescences but are generally greater than for 'Golden Hills'. 'Gumdrop' flowers about $10 \mathrm{~d}$ before 'Kerman' (Table 1). The male cultivar Tejon (U.S. Plant Patent application submitted 4 Apr. 2016) is the recommended pollinizer for 'Gumdrop' since existing commercial pollenizers 'Randy' (Parfitt et al., 2010) and 'Peters' (Parfitt et al., 2012) flower too late to provide pollen for 'Gumdrop' females.

Fruit and nuts. Fruits are drupes arranged in panicle clusters (Fig. 3). Fruit clusters are much larger, but fewer in number, than is typical for either 'Kerman' or 'Golden Hills', often with more than 100 nuts/cluster. Husk color gradually changes from a light green in late June to a cream white (149D, 150D, some 145D) with a pinkish tip (distal end) near maturity (149D, 150D, some 145D) and stem end scores of 149D, 150D, and some 145D. Kernel evaluations were done on three or more nuts. Kernels are a light green on the back (143D) and purple-pink on the kernel face (80B, 80C) (Fig. 4). Husks (exomesocarp) initially adhere tightly to the shell (endocarp), become detached, yet remain intact at harvest. Shells split in midseason, usually 4-6 weeks before harvest but remain enclosed in the husk. An unusual characteristic of this cultivar are the gummy deposits on the surfaces of the individual fruits, hence the name 'Gumdrop'. Although this is a less than desirable characteristic to growers, it has not been an issue for processors and the other quality metrics (see description in Performance Section below) make this cultivar a desirable alternative to the industry standard 'Kerman'. 'Gumdrop' produces a processed nut that is very similar to 'Kerman' or 'Golden Hills' in size and color. In-shell nuts are oval, longer than wide with a somewhat truncate base, and have a slightly cuspidate to rounded tip (Fig. 5), length $=2.04 \mathrm{~cm}(\mathrm{SD}=0.03)$, width $=1.33 \mathrm{~cm}$ $(\mathrm{SD}=0.05)$, similar to 'Kerman' (length $=$ $2.02 \mathrm{~cm}$ and width $=1.30 \mathrm{~cm}$ ) and 'Golden Hills' (length $=2.06 \mathrm{~cm}$ and width $=1.31$ $\mathrm{cm})$. 'Gumdrop' nuts are significantly wider

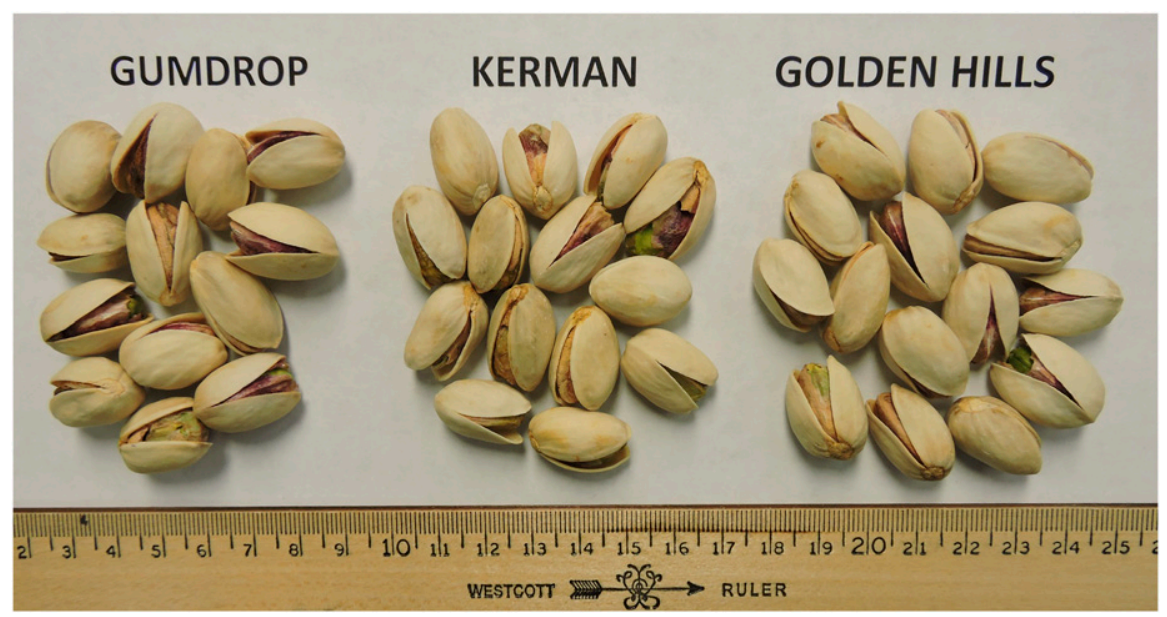

Fig. 5. Dry in-shell nuts of 'Gumdrop', 'Kerman', and 'Golden Hills'.

HortScience Vol. 52(2) February 2017

than 'Kerman', but no other nut size comparisons were significantly different. Shell suture depth is similar to 'Golden Hills'. Inshell nuts do not have the longer shell sutures on one side that are typical for 'Kerman'.

\section{Performance}

'Gumdrop' was released because of its early harvest date, which is $23.5 \mathrm{~d}$ before 'Kerman' and 10.3 d before 'Golden Hills' (Table 2). It also flowers much earlier than any other commercial cultivar, so we expect that it may perform better under low-chill conditions (Ghrab et al., 2014; Luedeling, 2012; Zhuang et al., 2016) such as those predicted for California's central valley within $40-60$ years (Luedeling et al., 2009).

Table 2 presents summary data for 'Gumdrop' compared with 'Kerman' and 'Golden Hills'. 'Kerman' is the standard cultivar that has been planted in California and elsewhere while 'Golden Hills' is a popular alternative due its nut quality characteristics, precocious yield, and earlier harvest date. Significant differences are indicated under mean values for each cultivar and $P$ values for GLM ANOVAs are given in the last five columns. Data were collected for 2012-15 seasons for means from six trees per cultivar (four trees for 'Kerman') in each of three blocks. Trunk circumference was measured once, on 16 June 2016, $10 \mathrm{~cm}$ above and below the graft union. The graft union was located $\approx 50 \mathrm{~cm}$ above the ground. Cross-sectional area was calculated from the measured circumference of the trunk assuming the trunk was circular.

'Gumdrop' payable yield was somewhat better than for 'Kerman' (ns) but less than for 'Golden Hills' in this trial. Payable yield, that portion of yield for which the grower is paid, does not include blank nuts or the shell weight from nonsplit shells containing a kernel (Administrative Committee for Pistachio, 2014). Split nut and blank nut percentages, important traits for grower returns were similar to 'Golden Hills' (ns) and significantly better than for 'Kerman'. Hulls that adhere to the shells during processing are undesirable. The percentage of adhering hulls is low for 'Gumdrop' $(<1 \%)$ and the two control cultivars. Insect damage was low $(<1 \%)$ and similar (ns) for all cultivars. Shell staining $(<1.3 \%)$ and loose shells $(<1 \%)$, were significantly higher for 'Gumdrop'. 'Loose shells' occur when the shells break apart during processing and separate from the kernels. 'Gumdrop' is a larger tree than either 'Kerman' or 'Golden Hills' at 10th leaf. Scion crosssectional area of 'Gumdrop' was also larger than for the other cultivars (Table 2). The cross-sectional area of the scion is larger than of the rootstock, to a greater extent than for 'Kerman' and 'Golden Hills'. The significance of scion/rootstock differences for future growth or yield is unknown (Kallsen and Parfitt, 2011). 
Table 2. Performance of 'Gumdrop' pistachio compared with 'Golden Hills' and 'Kerman', in a randomized block trial near Buttonwillow, CA. Letters below means show significance at $95 \%$ as determined from Bonferroni ranges.

\begin{tabular}{|c|c|c|c|c|c|c|c|c|c|}
\hline Trait & $\begin{array}{l}\text { Measurement } \\
\text { units }\end{array}$ & Gumdrop & Kerman & $\begin{array}{l}\text { Golden } \\
\text { Hills }\end{array}$ & $\begin{array}{c}\text { ANOVA } \\
P \text { value } \\
\text { for cultivar }\end{array}$ & $\begin{array}{l}\text { ANOVA } P \\
\text { value for } \mathrm{yr}\end{array}$ & $\begin{array}{c}\text { ANOVA } \\
P \text { value } \\
\text { for cultivar*yr }\end{array}$ & $\begin{array}{c}\text { ANOVA } \\
P \text { value } \\
\text { for block }\end{array}$ & $\begin{array}{c}\text { Total } \\
\text { df }\end{array}$ \\
\hline$\overline{\text { ANOVA df }}$ & & & & & 2 & 3 & 6 & 2 & 35 \\
\hline \multirow[t]{2}{*}{ Payable yield mean } & $\mathrm{kg} / \mathrm{ha}$ & 1,408 & 1,270 & 1,662 & 0.000 & 0.000 & 0.000 & 0.433 & \\
\hline & $\mathrm{lb} / \mathrm{ac}$ & $1,257 \mathrm{a}$ & $1,134 \mathrm{a}$ & $1,484 \mathrm{~b}$ & & & & & \\
\hline Split nut percentage mean & $\%$ & $85.9 \mathrm{a}$ & $71.5 \mathrm{~b}$ & $87.5 \mathrm{a}$ & 0.000 & 0.000 & 0.296 & 0.274 & \\
\hline Blank nut percentage & $\%$ & $5.97 \mathrm{a}$ & $11.2 \mathrm{~b}$ & $4.38 \mathrm{a}$ & 0.000 & 0.000 & 0.458 & 0.078 & \\
\hline Insect damage percentage & $\%$ & $0.99 \mathrm{a}$ & $0.95 \mathrm{a}$ & $0.55 \mathrm{a}$ & 0.151 & 0.010 & 0.000 & 0.114 & \\
\hline Nut weight & $\mathrm{g} /$ nut & $1.35 \mathrm{a}$ & $1.38 \mathrm{a}$ & $1.35 \mathrm{a}$ & 0.850 & 0.382 & 0.122 & 0.656 & \\
\hline Loose shells & $\%$ & $0.84 \mathrm{a}$ & $0.25 \mathrm{~b}$ & $0.28 \mathrm{~b}$ & 0.000 & 0.056 & 0.061 & 0.912 & \\
\hline Adhering hulls & $\%$ & $0.70 \mathrm{ab}$ & $1.59 \mathrm{~b}$ & $0.51 \mathrm{a}$ & 0.012 & 0.089 & 0.357 & 0.666 & \\
\hline Stain fraction & $\%$ & $1.22 \mathrm{a}$ & $0.30 \mathrm{~b}$ & $0.58 \mathrm{a}$ & 0.001 & 0.001 & 0.923 & 0.611 & \\
\hline $\begin{array}{l}\text { Harvest date: days after } 1 \\
\text { Aug. }\end{array}$ & days & $18.3 \mathrm{a}$ & $41.8 \mathrm{~b}$ & $28.6 \mathrm{c}$ & 0.000 & 0.000 & 0.000 & 0.422 & \\
\hline Trunk XC area (Scion) & $\mathrm{cm}^{2}$ & $342 \mathrm{a}$ & $185 \mathrm{~b}$ & $190 \mathrm{~b}$ & 0.000 & $*$ & $*$ & 0.857 & \\
\hline Trunk XC area (rootstock) & $\mathrm{cm}^{2}$ & $256 \mathrm{a}$ & $215 \mathrm{ab}$ & $196 \mathrm{~b}$ & 0.055 & * & $*$ & 0.887 & \\
\hline
\end{tabular}

*data collected in 2016 only.

\section{Availability}

Budwood of 'Gumdrop' is being distributed to California nurseries and commercial budders in 2016 and should be available in small quantities from those sources beginning in 2018. Lists of nurseries producing 'Gumdrop' will be available from the UC Davis Technology Transfer Services, UC Davis Innovation Access, 1850 Research Park Drive, Suite 100, Davis, CA 95618-6159, www. research.ucdavis.edu/InnovationAccess.

\section{Literature Cited}

Administrative Committee for Pistachios. 2014. Receipts/assessments/report instructions, Crop Year 2-14: 2015 Fresno, Calif. OMB no. 0581-0215. 16 June 2015. <https://www.ams.usda.gov/sites/ default/files/media/ACP-1-PistachioReceipt Assessment.pdf>.
Chao, C.T., D.E. Parfitt, L. Ferguson, C. Kallsen, and J. Maranto. 1998. Breeding and genetics of pistachio: The California program. Proc. $2 \mathrm{~d}$ Int. Symposium on Pistachios and Almonds, Aug. 24-29, 1997, Davis CA, USA. Acta Hort. 470:152-161.

Ghrab, M., M.B. Mimoun, M.M. Masmoudi, and N.B. Mechlia. 2014. Chilling trends in a warm production area and their impact on flowering and fruiting of peach trees. Sci. Hort. 178:8794.

Kallsen, C.E. and D.E. Parfitt. 2011. Comparison of scion/rootstock growth rates among U.S. pistachio cultivars. HortScience 46:1-4.

Kallsen, C.E., D.E. Parfitt, J. Maranto, and B. Holtz. 2009. New pistachio varieties show promise for California cultivation. Calif. Agr. 63:18-23.

Luedeling, E. 2012. Climate change impacts on winter chill for temperate fruit and nut production: A review. Sci. Hort. 144:218-229.
Luedeling, E., M. Zhang, and E.H. Girvetz. 2009. Climatic changes lead to declining winter chill for fruit and nut trees in California during 1950-2099. PLoS One 4:E6166, doi: 10.1371/journal.pone.0006166.

Parfitt, D.E., S. Kafkas, I. Batlle, F.J. Vargas, and C.E. Kallsen. 2012. Pistachio, p. 803-826. In: M.L. Badenes and D.H. Byrne (eds.). Fruit breeding. Springer, New York, NY.

Parfitt, D.E., C. Kallsen, J. Maranto, and B. Holtz. 2007. 'Golden Hills' Pistachio. HortScience 42:694-696.

Parfitt, D.E., C.E. Kallsen, B. Holtz, and J. Maranto. 2010. 'Randy' Male Pistachio. HortScience 45:1113-1115.

Royal Horticultural Society; R.H.S. colour chart v. 3. R8 V. 1-4.

Zhuang, W., B. Cai, Z. Gao, and Z. Zhang. 2016. Determination of chilling and heat requirements of 69 Japanese apricot cultivars. Eur. J. Agron. 74:68-74. 